\title{
Peacemaking in Iran
}

The questions of whether religion can contribute toward resolving and preventing conflict, and to what extent a modern nation can balance culture, politics, and tradition, were raised at the one-day conference on "Dialogues of Peace in Islam" hosted by the UNESCO Chair for Human Rights, Peace and Democracy at Tehran's Shahid Beheshti University.

The conference provided interaction with the seven-member delegation of Muslim American scholars of Islam and conflict resolution who traveled in Iran for ten days during October 2007. They met with Iranian experts to better understand their approaches to peacemaking, conflict prevention, dialogue, and conflict resolution. They also met with lawyers, human rights experts, nongovernmental organizations, academicians, university students, social scientists, senior religious leaders, and theologians.

Ayse Kadayifci (professor of conflict resolution studies, American University), and Amr Abdalla (professor and vice rector for academic affairs, University for Peace in Costa Rica) presented various western and Islamic models of conflict assessment and areas where these models may or may not converge. The Iranian academicians focused on religion's role in defending human rights, democracy, and promoting equality. Abdul Hayy Weinman (professor, University of New Mexico) spoke about the Sunni-Shi`ah dialogues, areas for reconciliation, and effective practices in dialogic encoun- 
ters within religious communities. Dr. Safi (Shahid Beheshti Law School) spoke about the theorization of dialogue and the problems of historical influences of culture that shape the understanding of self in dialogue.

Karim Douglas Crow (professor, S. Rajaratnam School of International Studies, Singapore) discussed the historical dimensions in the early generation of Muslim communities that added to the formation of Sunni and Shi ah traditions. Ayatollah Seyed Mostafa Mohaghegh Damad (philosophy chair, Shahid Beheshti) responded: "We need to focus on community building and increasing dialogues on practical areas of governance, rule of law, and leadership." I presented a talk on "The intersection of American-Islamic practices and U.S. civil law" to a seminar at Beheshti's Law school.

Faculty members of the law school, as well as of the history, philosophy, anthropology, literature, and sociology departments, and undergraduate and graduate students from area universities attended. Many students fluent in French, German, and English asked about justice, international and religious law, authority and interpretation in Islam, and the applicability of conflict resolution skills. There is a tremendous amount of internal debate among liberals, reformists, leftists, conservatives, religious and secular people, and students and academicians. Iran has an energetic intelligentsia interested in gradual reform; the critical component was for the rule of law to protect its citizens and treat individuals as equals. Contrary to the negative western media images of mullahs dictating the thought and movement of Iranians, there is an immense degree of self-criticism, reflection, lively debate, and strong opinions.

In Qom, almost 100 miles south of Tehran, the delegation met with theologians, academicians, students, and three eminent grand ayatollahs. This center for Shi ah higher education, both for theological and liberal arts studies, has more than two dozen universities, seminaries, and research centers and is renowned for the shrine of Fatima Ma`sumah, sister of Imam `Ali ibn Musa Rida (d. $816 \mathrm{CE}$ ), the eighth Imam. The world's largest center for Shi ah scholarship, it is also a significant destination of pilgrimage.

At Al-Hauza Al-Ilmiyaa (The Seminary of Knowledge), one of Qom's preeminent theological institutions, Shi ah theologians and the Muslim American scholars discussed the particular understandings of peace and conflict. There is a tremendous amount of Shi ah literature on "just war," the theories of which differ from traditional Sunni premises. Shi ah theologians agreed that fighting, if necessary, is restricted to defense and never for an offensive war. Violence results from the breakdown of peaceful relations, and followers are theologically mandated to resolve conflicts peacefully. 
Al-Hauza theologians stressed that dialogue and interfaith cooperation is an established practice in Islam, and a responsibility in a time when religious extremism is on the rise. They stressed the importance of engaging with all leaders in order to create a peaceful world and displayed an exceptional degree of tolerance, offering the benefits of participation in their culture of debate and scholarship. The Shi ah scholars view themselves as continuing a rich intellectual tradition that respects others while being open to learning from outside. Several theologians, who have reached the status of ayatollahs, had doctorates from western universities, and spoke two or three western languages were accustomed to interacting with western scholars and spoke of current exchange programs with European scholars.

At least two al-Hauza theologians, while presenting their analysis in comparative theological terms, frequently referred to Karl Rahner, Paul Tillich, Dietrich Bonhoeffer, Thomas Aquinas, Wilfred Cantwell Smith, and John Wesley. They not only knew these Christian authors thoroughly, but also offered a comparative analysis to Shi ah Islam and ways in which there may be areas of similar discourse, thereby indicating a high level of command of works on Christianity. They wanted Muslim American scholars to remember the extent of shared histories that exists between Islam and Christianity.

In Qom, Mofid University's Center for Religion and Human Rights held a symposium at which Vice-provost Nasser Ghorbannia told the audience: "It is urgent and compulsory on us as scholars to have a dialogue between different opinions [in order] to have reconciliation and peace." He continued: "There are accusations that peace, equality, and fairness are not compatible to the Islamic tradition. We must address these statements. However, as a Mus$\mathrm{lim}$, we need to deal with these issues seriously and simultaneously engage in intra-faith dialogue to find common ground amongst ourselves. We need to recognize human dignity and equality."

Dr. Abu-Nimer (USIP) said the human rights field rarely includes religious scholars or the works of theologians and that, impressively, Mofid has a research center dedicated to this area. Several students differed on the definitions of peace studies and offered their versions from literature, religion, politics, or history. One expressed the need to have a structured program linked to western universities in order to pursue graduate studies. Another student felt that universities in general did not factor in the role of the arts, music, films, and theatre in peacemaking; however, any peace studies program must contain all aspects of culture. Among students there was a general desire to expand the peace studies and conflict resolution program. Faculty members were interested in working collaboratively on this project. 
Delegation members met with Grand Ayatollahs Vahid Khorasani, Mousavi Ardebili, and Yousef Sanei, who hold public offices and are influential in the religious and political culture of Iran. In the early 1980s, Ardebili, realizing that seminarians lacked a modern liberal arts education, established Mofid. Today, the university receives over 25,000 applications for less than 1,600 slots. More than 4,000 students attend Ardebili's weekly lectures.

The three ayatollahs represent different positions: conservative to reformist. Each spoke about the necessity of being just to each other - that justice must start with the individual's heart. Khorasani spoke about majestic presence of the divine in all living creatures, reminding people that whenever one small act of injustice occurs, it is a violation of our trust with the divine. For scholars of conflict resolution, his talk was another reminder of merging both the mind and the heart in their work.

Ardebili, former head of the Iranian judiciary and a marja taqlid ("source to follow"), insisted on greater dialogue between western and eastern leaders, and on the importance of not losing focus on establishing peace. "Dialogues," he stated, "have no obstacles. Rather, it is the individuals involved that create difficulty in dialoging. Individuals want to find problems and obsess over them, but rarely ask themselves 'Who created these obstacles?" He elaborated on dialogues ranging from religious (interfaith and intra-faith) to the political, social, cultural, legal, artistic, economical, and intellectual fields. His talk was refreshing, as it asked us to reflect on ways individuals understand a conflict and how perception can be a factor in resolving or exacerbating it.

Sanei, another marja taqlid, is a popular scholar, activist, jurist, and philosopher whose sermons are common on television; his websites are in Persian, English, and French. A staunch reformist and persistent government critic, Sanei has vigorously opposed the development of nuclear weapons and other weapons of mass destruction. He is extremely vocal against suicide bombing, religious extremism, terrorism, and fundamentalist movements, which he says are baseless in Islamic jurisprudence. Sanei repeated: "Equality means absolute equality - there is no room for discrimination. Those who use religious texts to defend violence are abusers of the faith!"

For many years Iran has been portrayed as a totalitarian religious society closed off to progress and modernity. Only in the past ten years has the portrayal of Iran begun to include images of a small band of reformers playing an important role in the social process. In reality, however, Iranian society is far more complex than even these images suggest. With a literacy rate of 92 percent, Iran has a vibrant civil society and intellectual life. Bookstores 
sell Persian, English, French, and German materials. While a vibrant grassroots reformist movement exists, it contains varieties of thought on how to improve Iranian society. It would be simplistic, if not careless, to present Iranians as either humanists/secularists and/or religious minded. There are individuals who traverse all of these worlds at certain times in their lives. On certain subjects, one may hold both religious reformist positions and also humanistic idealism. Their debates and exchanges were memorable because these individuals spoke about their vision of an alternative society. Arguments over religion were fascinating, since some scholars felt that the fusion of politics and religion is baseless in Islamic jurisprudence. Citing western societies as examples, some argued that a modern nation state cannot equate the ideals of liberty and equality with the influence of religion. These heated conversations appeared to flow naturally in this community. Nothing stood out as unusual, and no one displayed a sense of intellectual fatigue on the subject.

The difficult challenge, Ghorbannia said, was how two nations can overcome intense political hostility without losing sight of the other's human dignity and equality. With intense world pressure on Iran and all of the negative images associated with that society, these comments reflected a grander vision of peaceful coexistence.

Whether in the East or in the West, the notion of religion and religious peacemaking is still finding its niche. Interestingly, the three grand ayatollahs in Qom never mentioned religion or religious peacemaking. They were not consumed with humanist versus religious paradigms; rather, their concerns were about responsibility and the common good. They did not label these as "religious," but as part of the human responsibility to create a just society. The variety of these dialogues indicated how much need there is to understand Iranians and to be open, to dialogue, and to be partners in peacemaking. 